\title{
Kualitas Organoleptik dan Total Plate Count Daging Babi yang Dibungkus Plastik dan Daun Jati
}

\section{(ORGANOLEPTIC QUALITY AND TOTAL PLATE COUNT OF PORK THAT WERE PACKED WITH PLASTIC BAG AND TICK TREE LEAF)}

\author{
Ni Luh Putu Sriyani, \\ Ni Luh Gede Sumardani , I Wayan Subrata \\ Fakultas Peternakan Universitas Udayana \\ Jl. Sudirman, Sanglah, Denpasar, Bali, Indonesia 80234. \\ Telepon. (0361) 235231 \\ Email : sriyaninlp@unud.ac.id
}

\begin{abstract}
ABSTRAK
Tujuan dari penelitian ini adalah untuk melihat kualitas organoleptik dan kandungan TPC (Total Plate Count) daging babi yang dibungkus dengan plastik dan daun jati pada masa simpan yang berbeda. Materi penelitian menggunakan daging babi landrace yang diperoleh di pasar tradisional Pasar Sanglah. Sampel yang digunakan adalah pada bagian otot longisimus dorsi (LD) sebanyak $500 \mathrm{~g}$ setiap ulangan. Data organoleptik dianalisis statistik nonparametrik dengan uji Hedonik menurut Mann-Whitney antara pembungkus plastik dengan daun jati dan Kruskal Wallis antara lama waktu simpan. Sementara kandungan TPC dianalis dengan menggunakan T-Test pada setiap lama simpan yang berbeda. Hasil analisis non parametrik daging babi Landrace yang dibungkus plastik pada variabel warna, aroma, tekstur, keempukan, dan penerimaan keseluruhan, nyata lebih rendah $(\mathrm{P}<0,05)$ daripada daging yang dibungkus daun jati pada lama simpan 4 jam, 8 jam maupun 12 jam. Daging yang dibungkus plastik kualitas organoleptik menurun secara nyata $(\mathrm{P}<0,05)$ dari penyimpanan 4 jam sampai 12 jam. Sementara daging yang dibungkus daun jati menghasilkan kualitas organoletik yang tidak berbeda nyata dari 4 jam sampai 12 jam penyimpanan. Kandungan TPC daging babi landrace yang dibungkus daun jati 2,55 x $10^{5}$ $\mathrm{cfu} / \mathrm{g}, 2,58 \times 10^{5} \mathrm{cfu} / \mathrm{g}, 2,65 \times 10^{5} \mathrm{cfu} / \mathrm{g}$ nyata lebih rendah daripada daging yang dibungkus plastik $2,05 \mathrm{x}$ $10^{5} \mathrm{cfu} / \mathrm{g}, 5,8 \times 10^{7} \mathrm{cfu} / \mathrm{g}, 7,4 \times 10^{7} \mathrm{cfu} / \mathrm{g}$ selama masa penyimpanan 4,8 maupun $12 \mathrm{jam}$. Simpulan dari penelitian ini adalah pembungkusan daging dengan daun jati mampu mempertahankan kualitas organoleptik daging babi landrace selama penyimpanan sampai 12 jam. Pembungkus daging dengan daun jati juga mampu menekan pertumbuhan kandungan TPC daging babi landrace selama penyimpanan sampai 12 jam.
\end{abstract}

Kata kunci: kualitas daging, babi landrace, plastik, daun jati

\begin{abstract}
The objective of the research were to observe organoleptic quality and Total Plate Count (TPC), of the pork that were packed with plastic bag and tick tree leaf on different lenght of storage time. Material of the research used was Lancrace pork that bought at Sanglah traditional market. Sample used was longisimus dorsi (LD) muscle. Organoleptic data were analysed by using nonparametric statistic of Hedonic Test according to Mann-Whitney on the pork that were packed with plastic bag and tick tree leaf but, for different length of storage time used Kruskal Wallis Test. While the TPC was analysed by using T-Test on each different storage time. Results of the research showed that the Lancrace pork that packed with plastic bag on colour variable, aromatic, texture, tenderness and all acceptability lower significantly $(\mathrm{P}<$ 0.05 ) than the pork packed with tick tree leaf on the length of storage time for 4,8 and 12 hours. The pork that packed with plastic bag its quality on organoleptic decreased significantly $(\mathrm{P}<0.05)$ of 4 up to 12 hours but, on it that packed with tick tree leaf non significantly different $(\mathrm{P}>0.05)$ on organoleptic of the 4 up to the 12 hours storage. The TPC contents of the pork that packed $2,55 \times 105 \mathrm{cfu} / \mathrm{g}, 2,58 \times 105 \mathrm{cfu} / \mathrm{g}$, $2,65 \times 105 \mathrm{cfu} / \mathrm{g}$ with tick tree leaf 2,05 x $105 \mathrm{cfu} / \mathrm{g}, 5,8 \times 107 \mathrm{cfu} / \mathrm{g}, 7,4 \times 107 \mathrm{cfu} / \mathrm{g}$ lower significantly compare to the pork packed with plastic bag on the 4,8 and 12 hours storage. From all of the results mentioned above it could be concluded that the pork pecked with tick tree leaf could to stand its organoleptic quality for up to 12 hours storage and it also capable to press growth of the contents of the TPC for up to 12 hours storage.
\end{abstract}

Key words: meat quality, landrace pork, plastic bag, tick tree leaf 


\section{PENDAHULUAN}

Masyarakat di Pulau bali pada umumnya mengkonsumsi daging babi sebagai salah satu sumber pangan berprotein tinggi. Hal ini disebabkan karena sebagian besar masyarakat di Pulau Bali adalah beragam Hindu yang tidak mengharamkan daging babi untuk dikonsumsi. Kawasan pengembangan ternak babi umumnya berada di permukiman masyarakat Hindu di Bali. Oleh karena itu perkembangan usaha peternakan babi di Bali memiliki prospek yang cukup baik. Mengingat dengan meningkatnya kesejahteraan masyarakat Bali, jumlah penduduk yang semakin bertambah dan timbulnya kesadaran masyarakat Bali akan pentingnya mengkonsumsi protein hewani menyebabkan kebutuhan akan protein hewani meningkat.

Dalam mengkonsumsi daging babi biasanya masyarakat atau konsumen membeli daging babi di pasar moderen maupun tradisional. Pedagang pada umumnya membungkus daging tersebut dengan kantong plastik. Namun dengan dikeluarkannya Peraturan Gubernur Bali (Pergub) No.97 Tahun 2018 tentang Pembatasan Timbulan Sampah Plastik Sekali Pakai maka membungkus daging dengan menggunakan plastik mulai menjadi perhatian. Dengan pergub tersebut maka diharapkan penggunaan plastik sebagai pembungkus hendaknya dikurangi termasuk dalam hal ini adalah sebagai pembungkus daging. Plastik dapat merusak ligkungan disamping itu plastik dapat menginisiasi adanya senyawa yang dapat merubah rasa dan bau produk yang disimpan didalammnya, dan senyawa tersebut bersifat toksik dan berbahaya bagi manusia (Moreira et al.2015). Bahan bahan alternatif yang sifatnya alami barangkali sangat tepat dikembangkan sebagai bahan pembungkus daging. Bahanbahan alami memiliki aktivitas menghambat mikroba yang disebabkan oleh komponen tertentu yang ada didalamnya. Salah satu bahan pembungkus alami yang sudah sering digunakan terutama di desa-desa di Pulau Bali adalah daun jati. Berdasarkan hasil uji fitokimia Purushotham et al., (2010), daun jati terdapat flavonoid, alkaloid, tanin, napthaquinones dan antrakuinon yang dapat menghambat pertumbuhan bakteri atau sebagai antibakteri. Daun jati mengandung zat antioksidan yang didominan jenis fenol (Oka et al .,2016). Membungkus daging dengan daun jati tidak digunakan setiap hari biasanya digunakan pada saat acara acara adat, dimana pada saat tersebut daging babi dibagikan kepada masyarakat desa.

Dalam upaya mensukseskan pergub tentang pembatasan penggunaan plastik maka perlu dilakukan penelitian tentang daun jati sebagai bahan pembungkus daging. Penelitian daun jati sebagai pembungkus daging belum banyak dilaporkan. Penelitian tentang daun jati yang diekstrak dan digunakan sebagai bahan organic film untuk preservatif alami daging telah dilaporkan mampu menghambat kerusakan mikrobiologis pada produk sosis sapi (Isnafia et al,.2014). Informasi dari masyarakat di desa yang sering menggunakan daun jati sebagai pembungkus daging babi landrace menyatakan pendapatnya bahwa daging yang dibungkus dengan daun jati memiliki daya simpan yang lebih baik. Daun jati digunakan sebagai pembungkus daging oleh masyarakat desa dengan mempertimbangkan bahwa daun jati mudah didapat dan memiliki permukaan yang lebar juga dapat melindungi produk pangan dari kerusakan (Putri., et al 2018). Namun belum ada data berapa lama daging babi landrace tersebut mampu disimpan dengan baik dengan daun jati sampai terjadinya pembusukan. Maka penelitian ini dilaksanakan untuk melihat kualitas organoleptik dan kandungan TPC (Total Plate Count) daging babi landrace yang dibungkus dengan menggunakan daun jati dibandingkan dengan plastik selama masa simpan yang berbeda.

\section{METODE PENELITIAN}

Materi penelitian menggunakan daging babi landrace yang dibeli di pasar tradisional Sanglah Denpasar Bali. Sampel yang digunakan adalah pada bagian otot longisimus dorsi (LD). Penelitian ini menggunakan dua perlakuan yaitu perlakuan jenis pembungkus daging yaitu pembungkus plastik dan pembungkus daun jati dan lama simpan yang berbeda yaitu 4 jam, 8 jam dan 12 jam. Masing masing kombinasi perlakuan dibutuhkan $2 \mathrm{~kg}$ yang terdiri dari 4 ulangan dan masing-masing ulangan menggunakan $500 \mathrm{~g}$ daging babi landrace yang dibeli dari tiga lapak pedagang daging di Pasar Sanglah. Pelaksanaan penelitian ini diawali dengan menyiapkan plastik dan daun jati. Daun jati yang digunakan dalam penelitian ini adalah daun jati yang tidak terlalu muda dan tidak terlalu tua, diambil pada posisi daun ke 2-4 dari pucuk. Sampel daging babi segar dibungkus 
dengan rapat dalam kantong plastik bening satu lapis untuk perlakuan pembungkus plastik dan satu helai daun jati untuk perlakuan pembungkus daun jati, kemudian disimpan selama 4 jam, 8 jam, 12 jam dalam suhu ruang. Untuk uji organoleptik digunakan panelis semi terlatih sebanyak 15 orang panelis. Data yang diperoleh dianalisis statistik nonparametrik dengan uji Hedonik menurut Mann-Whitney (Saleh, 1996), antara dua perlakuan yaitu perlakuan dengan pembungkus plastik dan daun jati dan Kruskal Wallis antara lama waktu simpan. Masing masing panelis diberikan sampel dengan memberikan pendapat berdasarkan tingkat kesukaan menggunakan kisaran angka penilaian yaitu 1 untuk sangat tidak suka, 2 tidak suka, 3 biasa/netral, 4 suka, dan 5 sangat suka (Mahmud et al.,2016).

Total plate count (TPC) merupakan teknik menghitung jumlah seluruh mikroba yang terdapat pada daging dengan menggunakan media PCA(Plate Count Agar). Caranya sebagai berikut: menghaluskan sampel daging menimbang sampel sebanyak $5 \mathrm{~g}$. Tahapan pengenceran dimulai dari membuat larutan sampel sebanyak $10 \mathrm{ml}$ (campuran $1 \mathrm{ml} / 1 \mathrm{~g}$ sampel $9 \mathrm{ml}$ larutan pepton). Dari larutan tersebut diambil $1 \mathrm{ml}$ dan dimasukkan ke dalam tabung reaksi berikutnya sehingga didapatkan pengenceran $10^{-2}$, begitu seterusnya sampai mencapai pengenceran yang diinginkan. Selanjutnya mengambil larutan dari 2 tabung reaksi terakhir $10^{-6}$ dan $10^{-7}$. Kemudian dilakukan penanaman dengan metode tuang ( Fardiaz,1989). Penanaman ini dilakukan di dalam ruang steril dan berdekatan dengan api bunsen, hal ini bertujuan untuk menghindarkan kontaminasi dari lingkungan luar, dengan jalan mengambil tingkat pengenceran $10^{-3}, 10^{-4}, 10^{-5}, 10^{-6}$ dan $10^{-7}$ dengan pipet masingmasing dituangi dengan media PCA (suhu $\pm 45^{\circ} \mathrm{C}$ ) ke dalam cawan petri sebanyak $20 \mathrm{ml}$ dan ditutup kembali. Selanjutnya dihomogenkan dengan menggerkakkan cawan petri dengan hati-hati biarkan hingga media memadat. Penanaman dibuat rangkap dua (duplo) ke dalam inkubator dengan suhu $37^{\circ} \mathrm{C}$ dalam kondisi terbalik, dan hasil dapat dihitung 2448 jam.

$\mathrm{TPC}=$ jumlah koloni $\mathrm{x}$ (faktor pengencer $\mathrm{x}$ volume $)^{-1}$

Data Total Plate Counts daging yang diperoleh, terlebih dahulu ditransformasi ke log Y selanjutnya dianalisis dengan menggunakan uji perbandingan T- Test antara dua perlakuan pembungkus, selanjutnya ditransformasi anti log untuk mengembalikan ke data asli untuk menampilkan di tabel hasil.

\section{HASIL DAN PEMBAHASAN}

Dari hasil uji organoleptik menunjukkan bahwa tingkat kesukaan konsumen lebih tinggi pada daging yang dibungkus daun jati daripada plastik selama penyimpanan yang berbeda. Tingkat kesukaan konsumen menurun dari angka 3 (biasa) menjadi angka 1 (sangat tidak suka) pada daging yang dibungkus plastik dari 4 jam sampai 12 jam penyimpanan. Sementara pada daging yang dibungkus daun jati tingkat kesukaan konsumen rata rata stabil di angka 4 (suka) menuju 5 (sangat suka). Ini menunjukkan bahwa daging yang dibungkus plastik selama 4 jam,8 jam maupun 12 jam sudah menunjukkan tanda tanda atau indikator yang tidak disukai konsumen antara lain warna yang mulai pudar/ pucat, tekstur yang mulai berlendir mulai dari 4 jam, aroma daging yang sudah mulai menurun dari khas bau daging segar bahkan sudah mulai agak busuk pada 8 jam penyimpanan dan berbau busuk pada 12 jam penyimpanan. Sementara pada daging yang dibungkus daun jati selama penyimpanan 4 jam, 8 jam sampai 12 jam masih menujukkan ciri-ciri organoleptik yang masih diterima konsumen/ panelis dengan tidak menunjukkan tanda tanda daging yang rusak atau busuk. Hasil penelitian ini lebih tinggi daripada penelitian Suandana., et al (2016) yang mendapatkan kualitas organoleptik daging babi landrace yang tidak dibungkus mendapat nilai penerimaan keseluruhan 3,61 (biasa menuju suka).

Tanda-tanda pembusukan daging yang dibungkus dengan plastik mulai terlihat setelah 8 jam penyimpanan. Daging terlihat mulai berlendir dan bau sudah mulai membusuk. Sementara pada daging yang dibungkus daun jati selama 4 jam, 8 jam maupun 12 jam tidak terlihat indikasi pembusukan. Hal ini menandakan kandungan zat-zat aktif pada daun jati mampu menekan perkembangbiakan bakteri pada daging hal ini terlihat pada Tabel 2. Peningkatan populasi bakteri akan merusak atau menurunkan kualitas sensoris/ organoleptik daging. Berdasarkan hasil uji fitokimia Purushotham et al. (2010), daun jati terdapat flavonoid, alkaloid, tanin, napthaquinones dan antrakuinon dapat menghambat pertumbuhan bakteri atau sebagai antibakteri. 
Tabel 1. Perbandingan kualitas organoleptik daging babi landrace yang dibungkus dengan plastik dan daun jati pada lama waktu simpan yang berbeda

\begin{tabular}{llcr}
\hline $\begin{array}{l}\text { Waktu } \\
\text { Pembungkusan }\end{array}$ & Variabel & Plastik & Daun Jati \\
\hline T4 $4^{2)}$ & Warna & $3,20^{\mathrm{a}}$ & $4,53^{\mathrm{d} 1)}$ \\
& Aroma & $3,13^{3) \mathrm{a}}$ & $4,13^{\mathrm{d}}$ \\
& Tekstur & $3,73^{\mathrm{a}}$ & $4,07^{\mathrm{d}}$ \\
& Keempukan & $3,07^{\mathrm{a}}$ & $4,33^{\mathrm{d}}$ \\
$\mathrm{T} 8$ & Penerimaan Keseluruhan & $3,13^{\mathrm{a}}$ & $4,20^{\mathrm{d}}$ \\
& Warna & & $4,71^{\mathrm{d}}$ \\
& Aroma & $2,88^{\mathrm{b}}$ & $4,35^{\mathrm{d}}$ \\
& Tekstur & $2,58^{\mathrm{b}}$ & $3,94^{\mathrm{d}}$ \\
& Keempukan & $3,06^{\mathrm{b}}$ & $4,00^{\mathrm{d}}$ \\
& Penerimaan Keseluruhan & $3,23^{\mathrm{b}}$ & $4,53^{\mathrm{d}}$ \\
& & $2,82^{\mathrm{b}}$ & $4,46^{\mathrm{d}}$ \\
& Warna & & $4,27^{\mathrm{d}}$ \\
& Aroma & $1,67^{\mathrm{c}}$ & $4,07^{\mathrm{d}}$ \\
& Tekstur & $1,20^{\mathrm{c}}$ & $4,07^{\mathrm{d}}$ \\
& Keempukan & $2,33^{\mathrm{c}}$ & $4,40^{\mathrm{d}}$ \\
\hline
\end{tabular}

Keterangan : - $1=$ Nilai dengan huruf yang berbeda menunjukan perbedaan nyata atau signifikan $(\mathrm{P}<0,05)$.

- 2 = T4 Waktu pembungkusan selama 4 jam, T8 waktu pembungkusan selama 8 jam, T12 waktu pembungkusan selama 12 jam

- 3 = Skala hedonik 1 sangat tidak suka, 2 tidak suka, 3 biasa, 4 suka, 5 sangat suka

Tabel 2. Total plate count daging babi yang dibungkus dengan plastik dan daun jati selama waktu yang berbeda

\begin{tabular}{lccc}
\hline Waktu Pembungkusan & Plastikcfu/g & Daun Jaticfu/g & Standar SNI 2009 \\
\hline T4 1 & $2,05 \times 10^{5 \mathrm{a}}$ & $2,55 \times 10^{5 \mathrm{a}}$ & $1 \times 10^{6}$ \\
$\mathrm{~T} 8$ & $5,8 \times 10^{7 \mathrm{a}}$ & $2,58 \times 10^{5 \mathrm{~b} 2 \mathrm{a}}$ & $1 \times 10^{6}$ \\
$\mathrm{~T} 12$ & $7,4 \times 10^{7 \mathrm{a}}$ & $2,65 \times 10^{5 \mathrm{~b}}$ & $1 \times 10^{6}$ \\
\hline
\end{tabular}

Keterangan : - $\quad$ 1= T4 waktu pembungkusan selama 4 jam, T8 waktu pembungkusan selama 8 jam, T12 waktu pembungkusan selama 12 jam

- 2 = Nilai dengan huruf yang berbeda menunjukan perbedaan nyata atau signifikan $(\mathrm{P}<0,05)$.

Pada penelitian produk pangan lainya seperti yang dilaksanakan oleh Putri et al ., 2018 pada tempe, pembungkus daun jati memberikan tingkat kesukaan rasa yang tertinggi dibandingkan pembungkus lainnya (daun pisang, daun waru, daun kakao dan plastik).

Dari hasil penelitian ini (Tabel.2) dapat dijelaskan bahwa pembungkusan daging babi selama 4 jam baik dengan menggunakan plastik maupun daun jati menghasilkan daging dengan kandungan TPC yang tidak berbeda nyata $(\mathrm{P}>0,05)$ dan masih di bawah ambang batas SNI 2009 sebesar $1 \times 10^{6} \mathrm{cfu} / \mathrm{g}$. Pada pembungkusan daging selama 8 jam dan 12 jam terlihat populasi TPC daging babi landrace yang dibungkus dengan menggunakan plastik nyata lebih tinggi $(\mathrm{P}<0,05)$ daripada daging yang dibungkus daun jati. Hal ini menunjukkan bahwa pembungkusan daging babi landrace menggunakan daun jati dapat berfungsi meng- 


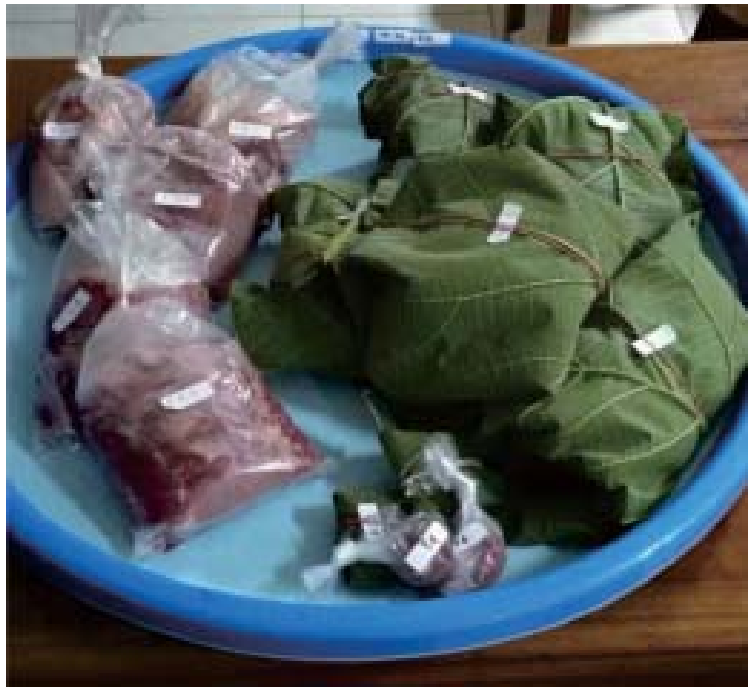

Gambar 1. Pembungkusan daging babi dengan plastik dan daun jati

hambat pertumbuhan bakteri. Senyawa aktif pada daun jati akan menghambat pertumbuhan bakteri pada daging babi segar. Berdasarkan penelitian Astiti (2015), menunjukkan bahwa senyawa aktif yang terdapat dalam ekstrak daun jati terdiri atas alkaloid, terpenoid, steroid, flavonoid dan fenolik. Wahyuni et al 2018 daun jati dari jenis pohon jati belanda juga mengandung flavonoid, alkaloid,tannin dan saponin. Alkaloid merupakan senyawa basa yang mengandung satu atau lebih atom nitrogen (Mangunwardoyo et al , 2009). Saponin mempunyai kemampuan menurunkan permeabilitas dinding sel bakteri dan menghambat pertumbuhannya (Sari et al, 2015). Flavonoid merupakan turunan dari senyawa fenol yang bekerja sebagai antimikroba (Arifin dan Ibrahim, 2018). Mekanisme antibakteri dari flavonoid ada tiga macam, yaitu dengan cara menghambat sintesis asam nukleat, menghambat fungsi membran sitoplasma, dan menghambat metabolisme energi. Selain itu senyawa flavonoid menyebabkan terjadinya kerusakan permeabilitas dinding sel bakteri. Senyawa bioaktif lainnya dengan kadar yang cukup tinggi yaitu senyawa fenol. Senyawa fenol sebagai senyawa antibakteri memiliki mekanisme dengan cara mendenaturasi protein dan merusak membran sel. Menurut Damayanti dan Suparjana (2007), golongan fenol mampu merusak membran sel, menginaktifkan enzim dan mendenaturasi protein sehingga dinding sel bakeri mengalami kerusakan karena penurunan permeabilitas. Hasil penelitian Rizky dan Sogandi (2018) ekstrak etanol daun jati memiliki kemampuan menghambat pertumbuhan bakteri Escherichia coli dan Staphylococcus aureus dimana bakteri ini merupakan bakteri pathogen yang sering ditemukan pada daging.

Daging babi landrace segar yang sampelnya diambil di Rumah Pemotongan Hewan $(\mathrm{RPH})$ tradisional mempunyai total plate count (TPC) sebesar $1,66 \times 10^{2} \mathrm{cfu} / \mathrm{g}$ (Priadi et al 2016). TPC pada daging yang sampelnya diambil pada RPH kata gori II memiliki kisaran nilai $1,4 \times 10^{3} \mathrm{cfu} / \mathrm{g}$ sampai $6 \times 10^{3} \mathrm{cfu} / \mathrm{g}$ ( Gaznur et al., 2017). Penghitungan total plate count sebagai indikator daya simpan daging karena jumlah mikroba/TPC pada daging erat hubungannya dengan kerusakan pada daging. Jumlah mikroba yang mencapai $10^{7} \mathrm{cfu} / \mathrm{g}$ atau lebih mengindikasikan daging sudah mulai mengalami pembusukan sesuai dengan pendapat Adams dan Moss (2008) yang menyatakan bahwa awal pembusukan pada daging segar adalah bau busuk yang timbul karena pertumbuhan mikroba mencapai jumlah $10^{7} \mathrm{cfu} / \mathrm{g}$ atau lebih. Hal ini menunjukkan pembungkusan daging babi landrace dengan menggunakan plastik selama 8 jam dan 12 jam sudah mengalami pembusukan. Hal ini disebabkan karena plastik tidak berpori yang menyebabkan kelembaban dan suhu naik, dan menimbulkan adanya aktivitas mikroba. Kelembabab dan suhu yang naik juga memicu terjadinya weep (keluarnya air daging) yang sangat memungkinkan menjadi media perkembangan bakteri pembusuk.

\section{SIMPULAN}

Konsumen lebih menyukai daging babi landrace yang dibungkus dengan daun jati daripada plastik. Terjadi penurunan tingkat kesukaan pada daging yang dibungkus plastik selama pembungkusan dari 4 jam sampai 12 jam. Pembungkus daging dengan daun jati mampu mempertahankan kualitas organoleptik daging selama penyimpanan sampai 12 jam. Pembungkus daun jati pada daging babi landrace mampu menekan pertumbuhan TPC selama masa simpan 12 jam dan masih berada di bawah ambang batas SNI 2009.

\section{SARAN}

Membungkus daging babi di ruang terbuka atau membungkus daging babi bagi pedagang 
pasar tradisional disarankan menggunakan daun jati daripada plastik.

\section{UCAPAN TERIMA KASIH}

Ucapan terimakasih disampaikan kepada Direktorat Jendral Pendidikan Tinggi atas biaya yang diberikan melalui Penelitian Unggulan Program Studi Sesuai dengan Surat Perjanjian Penugasan Pelaksanaan Penelitian Nomor : 690j/UN14.2.3.II/PNL/2019. Terima kasih juga penulis sampaikan kepada staf laboratorium Teknologi Hasil Ternak dan Mikrobiologis Fakultas Peternakan Universitas Udayana.

\section{DAFTAR PUSTAKA}

Adam, M. R and Moss, M. O. 2008. Food Microbiology Third Edition. The Royal Society of Chemictry, England.

Astiti A.N.P 2015 Efektivitas Ekstrak Daun Jati ( Tectona Grandis L. F) Dalam Menghambat Pertumbuhan Jamur Hormiscium Sp. Jurnal Bumi Lestari, Volume 15 No. 1, Pebruari 2015, hlm. 66 70

Arifin B, Ibrahim S, 2018. Struktur Biokativitas dan Antioksidan Flavonoid. Jurnal Zarah, Vol. 6 No.1, hlm 21-29

Damayanti, E. dan Suparjana T.B, 2007. Efek Penghambatan Beberapa Fraksi Ekstrak Buah Mengkudu Terhadap Shigella Dysenteriae. Prosiding Seminar Nasional Teknik Kimia Kejuangan. Fakultas Biologi Universitas Jenderal Soedirman.

Fardiaz, S. 1989. Analisis Mikrobiologi Pangan, Departemen Pendidikan Tinggi, Pusat Antar Universitas Pangan dan Gizi. Institut Pertanian Bogor

Gaznur Z.M., Nuraini H., Priyanto R., 2017. Evaluasi Penerapan Standar Sanitasi dan Higien di Rumah Potong Hewan Katagori II. Jurnal Veteriner Vol. 18 No 1, hlm 107 115

Isnafia A, Suryati I., Afiyah T.D.N and Wardhani D.P., 2014. Physicochemical and Organic of Beef Sausage With Teak Leaf Extract (Tectona Grandis) Addition as Preservative and Natural Dye. International Food Research Jurnal Vol 21 No 5
Mangunwardoyo W., Eni C., Tepy U. 2009. Ekstraksi dan Identifikasi Senyawa Antimikroba Herba Meniran (Phyllanthus niruri L.). Jurnal Ilmu Kefarmasian, Volume 7 N0 2 September 2009, hlm 57-63

Moreira. M.A., Andre L.C., and De Lourders C.Z., 2015. Analysis of Plasticizer Migration to Meat Roasted in Plastic Bags by SPMEGC/MS. Food chemistry, 178,pp.115-130

Mahmud A.T.B.A., Afnan R, Ekastuti D.R.,Arief I.I.,2017. Profil Darah, Performans dan Kualitas Daging Ayam Persilangan Kampung Broiler pada Kepadatan Kandang Berbeda. Jurnal Veteriner Vol.18 N0.2, hlm 247-256

Oka A.A., Wiyana K.A., Sugitha I.M dan Miwada I.N.S, 2016. Identifikasi Sifat Fungsional dari Daun Jati, Kelor dan Kayu Manis dan Potensinya sebagai Sumber Antioksidan pada Edible Film. Jurnal Sain Peternakan Indonesia Vol. 11 No 1 Januari-Juni 2016

Purushotham KG., Arun P, Jayarani JJ, Vansthakumari R, Sankar L, Reddy BR. 2010. "Synergistic in vitro antibacterial activity of Tectona grandis leaves with tetracycline." Int J.PharmTech Res.

Priadi, I G. D., Sriyani N.L.P dan Lindawati S.A 2016. Tingkat Cemaran Mikroba Daging Babi Bali dan Daging Babi Landrace. Peternakan Tropika Vol. 4 No. 3 Th. 2016: $673-684$

Putri B.D., Widyastuti S.,Werdiningsih W.,2018. Tempe Kacang Komak dengan Beberapa Pembungkus yang Berbeda Selama Fermentasi. Pro food (Jurnal Ilmu dan Teknologi Pangan) Vol. 4 No 2

Saleh. S 1996. Statistik Non Parametrik. Penerbit BPFE Yogyakarta

Sari, I.P., Wibowo M.A., dan Arreneuz S . 2015. Aktivitas Antibakteri Ekstrak Teripang Butoh Keling (Holothuria leucospilota) Dari Pulau Lemukutan Terhadap Bakteri Propionibacterium Acnesdan Staphylococcus Epidermidis. Jurnal Kimia Khatulistiwa, 4(4):21-28

Standard Nasional Indonesia (SNI 7388, 2009). Batas Maksimun Cemaran Mikroba pada Pangan. Badan Standarisasi Nasional (BSN). 
Suandana, I W., Sriyani N.L.P., Hartawan M, 2016. Studi Perbandingan Kualitas Organoleptik Daging Babi Bali dan Babi Landrace. Jurnal Peternakan Tropika Vol. 4 No 2 Th 2016: 405-418

Rizky T A, Sogandi 2018. Uji Aktivitas Antibakteri Ekstrak dan Fraksi Daun Jati (Tectona Grandiss Linn.F ) dalam Menghambat Pertumbuhan Bakteri Escherichia colidan Staphylococcus aureus Secara In Vitro. Indonesia Natural Research Pharmaceutical Journal (Vol. 3, No. 1, Maret 2018-Agustus2018)
Wahyuni S., Rissa L.V., Agitya R.E 2018. Kajian Aktifitas Antibakteri Ekstrak Etanol Daun Jati Belanda (Guazuma Ulmifolla Lamk) terhadap Pertumbuhan Streptococcus Mutans. Jurnal Inovasi Teknik Kimia, Vol. 3, No1, April 2018, Hal. 25-30 